\title{
Cupriavidus necator strains: zinc and cadmium tolerance and
} \section{bioaccumulation}

\author{
Paulo Ademar Avelar Ferreira ${ }^{*}$, Cleide Aparecida Bomfeti², Cláudio Roberto Fonsêca de Souza Soares ${ }^{3}$, Bruno Lima Soares ${ }^{4}$, Fatima \\ Maria de Souza Moreira ${ }^{4}$
}

${ }^{1}$ Federal University of Santa Maria - Dept. of Soil Science, Av. Roraima, 1000 - 97105-900 - Santa Maria, RS - Brazil. 2Federal University of Vales of Jequitinhonha and Mucuri/ Institute of Science and Technology, R. do Cruzeiro, 01 39803-371 - Teófilo Otoni, MG - Brazil.

${ }^{3}$ Federal University of Santa Catarina/Biological Sciences Center - Microbiology, Immunology and Parasitology Dept., C.P. 476 - 88040-900 - Florianópolis, SC - Brazil.

${ }^{4}$ Federal University of Lavras - Dept. of Soil Science, C.P. 3037 - 37200-000 - Lavras, MG - Brazil.

*Corresponding author < paulo.ferreira@ufsm.br>

Edited by: Fernando Dini Andreote

Received February 27, 2017

Accepted July 24, 2017
ABSTRACT: Among soil microorganisms, the genus Cupriavidus has garnered particular scientific, economic and ecological interest because of its ability to fix nitrogen and tolerate high concentrations of metals. The aim of this study was to analyze four strains of Cupriavidus necator for their ability to tolerate and bioaccumulate cadmium and zinc. The tolerance of these strains to these metals was assessed in liquid culture medium containing different concentrations of $\mathrm{Zn}$ $+\mathrm{Cd}$ and in soil solutions and soils contaminated with multiple elements including $\mathrm{Zn}, \mathrm{Cd}, \mathrm{Cu}$ and $\mathrm{Pb}$. The four strains showed high tolerance to $\mathrm{Zn}$ and $\mathrm{Cd}$, both in culture medium and when inoculated into contaminated soil solutions or multi-element contaminated soil. The UFLA02-71 strain displayed the highest ability to bioaccumulate these metals. It was able to accumulate 93.76 $\mu \mathrm{mol} g$ cell ${ }^{-1}$ of $\mathrm{Zn}$ and $16.03 \mu \mathrm{mol} \mathrm{g} \mathrm{cell}^{-1}$ of $\mathrm{Cd}$ when cultured in liquid medium with a total heavy metal concentration of $9,140 \mu \mathrm{mol} \mathrm{L}-1(9,000 \mathrm{Zn}+140 \mathrm{Cd})$ and was able to accumulate 16.98 $\mu \mathrm{mol} \mathrm{g} \mathrm{cell}^{-1}$ of $\mathrm{Cd}$ in the soil solution. An increase in the $\mathrm{pH}$ of the culture medium resulting from the growth of the $\mathrm{C}$. necator strains reduced the $\mathrm{Zn}^{2+}$ and $\mathrm{Cd}^{2+}$ ions in the medium and increased the concentrations of the $\mathrm{ZnHPO}_{4}$ and $\mathrm{CdHPO}_{4}$ species in solution. Thus, we concluded that they show great potential for use in the bioremediation of HM-contaminated areas.

Keywords: $\beta$-proteobacteria, bioremediation, heavy-metal, soil pollution

\section{Introduction}

Several microorganisms are capable of colonizing HM-contaminated environments due to a wide range of mechanisms and interactions that allow them to adapt to these environments (Sharaff and Archana, 2015). In general, the main tolerance mechanisms of microorganisms are related to the active transporting of metals across the membrane and out of the cell, resistance plasmids with genes encoding to heavy metal tolerance, adsorption of metals by the cell wall, and biotransformation of the metals directly by specific enzymes or indirectly by cellular metabolites (Gadd, 2004).

Among the soil microorganisms capable of colonizing HM-contaminated environments, nitrogen-fixing bacteria (NFB) that form symbioses with legumes are particularly notable (Vázquez et al., 2006). Among the bacteria that can fix nitrogen in symbiosis with legumes, the species Cupriavidus taiwanensis (syn. Ralstonia taiwanensis) has been shown to be able to both efficiently nodulate the legume Mimosa pudica (Chen et al., 2001, 2003a, b) and accumulate $\mathrm{Pb}, \mathrm{Cd}$ and $\mathrm{Cu}$ (Chen et al., 2008). Other species of the Cupriavidus genus that were isolated from tailing pond sediments at a zinc factory have also garnered interest for their potential use in bioremediation, including Cupriavidus metallidurans, although this specie does not fix nitrogen. These species are well known for being highly tolerant of $\mathrm{Zn}, \mathrm{Cd}, \mathrm{Co}$, $\mathrm{Ni}, \mathrm{Cu}, \mathrm{Cr}, \mathrm{Hg}$ and $\mathrm{Pb}$ (Taghavi et al., 1997; Goris et al., 2001; Mergeay et al., 2003) and for their ability to biodegrade recalcitrant xenobiotic compounds (Louie et al., 2002; Trefault et al., 2004). Notably, C. taiwanensis strains, unlike C. metallidurans strains, have been isolated from the nodules of Mimosa sp. in uncontaminated environments in Taiwan (Chen et al., 2008), suggesting that the location of origin does not influence metal tolerance in this genus. Recently, the ability of $C$. necator to symbiotically fix nitrogen in legumes (Silva et al., 2012; Ferreira et al., 2013) and to tolerate heavy metals in a solid medium (Ferreira et al., 2012) has been shown. However, there are no studies examining the tolerance of Cupriavidus necator under multi-element HM-contamination conditions either in culture medium or using contaminated soils.

Because species of this genus have potential applications for heavy metal biosorption and have the ability to nodulate legumes, the aim of this study was to assess the zinc and cadmium tolerance and bioaccumulation by Cupriavidus necator strains in liquid culture medium, soil solutions and multi-element contaminated soil.

\section{Materials and Methods}

\section{Sampling and chemical characterization of multi- element contaminated soil}

Soil samples contaminated with multiple elements including $\mathrm{Zn}, \mathrm{Cd}, \mathrm{Cu}$ and $\mathrm{Pb}$ which were classified as Red-Yellow Latosol (Hapludox), a dystrophic plinthic soil, were collected in the Votorantim Metais (VM) industrial area located in the municipality of Três Marias (18 $11^{\prime} 11^{\prime \prime} \mathrm{S}$; $45^{\circ} 14^{\prime} 36^{\prime \prime} \mathrm{W}$; $557 \mathrm{~m}$ altitude) (Minas Gerais, Brazil). These samples were collected during Feb 2009 at a depth of 0-20 cm. In total, 5 composite samples were collected and each composite sample consisted of 
5 single samples. Chemical characterization of the soil solution was then performed to determine the available concentrations of $\mathrm{Zn}$ and $\mathrm{Cd}$. For this analysis, a saturation extract was produced following the methodology described by Van Raij et al. (2001), which included five replicates. The concentrations of the elements were determined via atomic absorption spectrophotometry (City: Überlingen, State: Baden-Württemberg, Country: Germany).

\section{Bacterial strains}

The bacterial strains used in this study had been previously isolated from the rhizosphere of the legume Sesbania virgata using Phaseolus vulgaris and Leucaena leucocephala as bait plants to isolate bacteria that nodulate legumes in uncontaminated soil (Florentino et al., 2009). The isolated bacterial strains showed rapid growth, resulting in alkaline culture medium and reduced gum production in medium 79 (Fred and Waksman, 1928). These strains were identified as $C$. necator by Silva et al., 2012 based on phenotypic characterization, 16S rRNA gene sequencing and sequencing of other housekeeping genes and comparison of these sequences with the NCBI database. The four strains (UFLA01-663, UFLA01-659, UFLA02-73 and UFLA02-71) were selected based on the efficiency of their symbioses with legumes that have the potential to revegetate degraded areas and their tolerance of $\mathrm{Cd}$ and $\mathrm{Zn}$ concentrations in solid culture medium (Ferreira et al., 2012).

Evaluation of growth of $C$. necator strains in LB liquid medium containing $\mathrm{Cd}$ and $\mathrm{Zn}$ and in a multi-element contaminated soil solution

Starter strains were grown in LB [Luria-Bertani] medium $\left(5 \mathrm{~g} \mathrm{~L}^{-1} \mathrm{NaCl}, 5.0 \mathrm{~g} \mathrm{~L}^{-1}\right.$ yeast extract and $10 \mathrm{~g}$ $\mathrm{L}^{-1}$ tryptone) (Sambrook et al., 1989) at $\mathrm{pH} 6.0$ with orbital agitation at $110 \mathrm{rpm}(0.68 \times \mathrm{g})$ at $28{ }^{\circ} \mathrm{C}$ until they reached an optical density (OD) at $560 \mathrm{~nm}$ of $1.0(1 \times$ $10^{9} \mathrm{CFU}$ [colony-forming units] $\mathrm{mL}^{-1}$ ). One milliliter of the inoculum was then transferred into $100 \mathrm{~mL}$ of $\mathrm{LB}$ liquid medium containing HEPES $\left(1.3 \mathrm{mg} \mathrm{L}^{-1}\right.$ de N-2-hydroxyethylpiperazine-N-2-ethane sulfonic acid) and MES [1.1 mg L $\mathrm{m}^{-1}$ de 2-(N-morpholino) ethane sulfonic acid] (Cole and Elkan, 1973) at pH 6.0. Different concentrations of $\mathrm{Zn}$ and $\mathrm{Cd}$ were added to this medium, resulting in $9.14 \mu \mathrm{mol} \mathrm{L}-1(9.0 \mathrm{Zn}+0.14 \mathrm{Cd}) ; 91.4 \mu \mathrm{mol} \mathrm{L}^{-1}(90$ $\mathrm{Zn}+1.4 \mathrm{Cd}) ; 914 \mu \mathrm{mol} \mathrm{L}-1(900 \mathrm{Zn}+14 \mathrm{Cd}) ;$ and 9,140 $\left.\mu \mathrm{mol} \mathrm{L}{ }^{-1}(9,000 \mathrm{Zn}+140 \mathrm{Cd})\right]$. The medium was then autoclaved at $121{ }^{\circ} \mathrm{C}$ for $20 \mathrm{~min}$. The concentrations of $\mathrm{Zn}$ and $\mathrm{Cd}$ were defined based on the levels of $\mathrm{Zn}$ and $\mathrm{Cd}$ found in the soil solution while maintaining the ratio of $64.3 \mathrm{Zn}: \mathrm{Cd}$ found in the multi-element contaminated soil solution.

The evaluation of the growth of $C$. necator in the soil solution was performed as described above except that the $\mathrm{Zn}: \mathrm{Cd}$ ratio was 32.16 in this solution. In addition, $5 \mathrm{~g}$ of $\mathrm{NaCl}, 5 \mathrm{~g}$ of yeast extract and $10 \mathrm{~g}$ of tryptone per liter of solution were added to the soil so- lution. This medium was autoclaved $\left(20 \mathrm{~min}\right.$ at $\left.121^{\circ} \mathrm{C}\right)$ and subsequently characterized by ion chromatography (City: Sunnyvale, State: California, Country: United States) and atomic absorption spectrophotometry (City: Überlingen, State: Baden-Württemberg, Country: Germany). The results were used for chemical speciation using the Visual MINTEQ program (Version 3.0) (This version was compiled in Visual Basic 2012 on 1 Oct 2014 by Jon Petter Gustafsson, KTH, Div. of Land and Water Resources Engineering, Stockholm, Sweden.) at $\mathrm{pH} 6.0$ (before growth) and $\mathrm{pH} 7.86$ (after $120 \mathrm{~h}$ of growth) to evaluate the distribution of $\mathrm{Zn}$ and $\mathrm{Cd}$ species in solution.

The cultures were incubated at $28{ }^{\circ} \mathrm{C}$ under agitation at $110 \mathrm{rpm}$. Samples were taken following 3, 6, 12, $24,48,72,96$ and $120 \mathrm{~h}$ of incubation. At each time point, $100 \mu \mathrm{L}$ aliquots were collected and diluted in 900 $\mu \mathrm{L}$ of $0.85 \%$ saline to determine the number of viable CFUs as described by Miles and Misra (1938).

\section{Survival of $C$. necator strains in multi-element contaminated soil}

The same methods as described above were used to evaluate the survival of strains in soil contaminated with multiple HM. The soil was sieved through $2.0 \mathrm{~mm}$ mesh, and $200 \mathrm{~g}$ of soil was then transferred to $500 \mathrm{~mL}$ Erlenmeyer flasks. These samples were autoclaved three times for $1 \mathrm{~h}$ at $121{ }^{\circ} \mathrm{C}$ and allowed to stand for 30 days to stabilize. These soils displayed the following chemical characteristics after autoclaving: $\mathrm{pH}=6.2 ; \mathrm{P}=37.6 \mathrm{mg}$ $\mathrm{dm}^{-3}$ (Mehlich I); $\mathrm{K}=36 \mathrm{mg} \mathrm{dm}^{-3} ; \mathrm{Ca}=1.8 \mathrm{cmolc} \mathrm{dm}^{-3}$; $\mathrm{Mg}=0.3 \mathrm{cmolc} \mathrm{dm}^{-3} ; \mathrm{H}+\mathrm{Al}=1.5 \mathrm{cmolc} \mathrm{dm}^{-3} ; \mathrm{Zn}=$ $12,514 \mathrm{mg} \mathrm{dm}^{-3} ; \mathrm{Cd}=12.4 \mathrm{mg} \mathrm{dm}^{-3} ; \mathrm{Pb}=18.3 \mathrm{mg} \mathrm{dm}^{-3}$; $\mathrm{Cu}=1,144.9 \mathrm{mg} \mathrm{dm}^{-3}$; and $\mathrm{MO}=1.8 \mathrm{dag} \mathrm{kg}^{-1}$. The semi-total concentrations (USEPA 3051A) (USEPA, 1998) of $\mathrm{Zn}, \mathrm{Cd}, \mathrm{Pb}$ and $\mathrm{Cu}$ were 47,910, 1,207, 6,488 and 738 $\mathrm{mg} \mathrm{kg}{ }^{-1}$, respectively.

Cultures of $C$. necator strains were grown in 20 $\mathrm{mL}$ of LB broth to an $\mathrm{OD}_{560}=1.0$ and transferred to Erlenmeyer flasks containing soil. The flasks were then rotated to ensure that the inoculum was uniformly distributed. Each assay was performed in triplicate. The moisture content of the inoculated soil was maintained at approximately $70 \%$ of the total pore volume (TPV) by weighing the flask and adding autoclaved distilled water. To assess the number of viable bacterial cells, $5 \mathrm{~g}$ of soil was added to $45 \mathrm{~mL}$ of $0.85 \%$ saline and the number of CFUs was then determined using serial dilutions (Miles and Misra, 1938) at 0,7,14,21, 28, 35 and 42 day intervals following inoculation.

\section{Bioaccumulation of $\mathrm{Zn}$ and $\mathrm{Cd}$ by the bacterial strains}

To evaluate the ability of the strains UFLA01-663, UFLA01-659, UFLA02-73 and UFLA02-71 to accumulate $\mathrm{Zn}$ and $\mathrm{Cd}, 1 \mathrm{~mL}$ aliquots of the bacterial starter cultures were transferred into $100 \mathrm{~mL}$ of LB medium which contained different concentrations of $\mathrm{Zn}+\mathrm{Cd}$ metals. 
The heavy metal concentrations used in this experiment were $9.14 \mu \mathrm{mol} \mathrm{L}-1(9.0 \mathrm{Zn}+0.14 \mathrm{Cd}) ; 91.4 \mu \mathrm{mol} \mathrm{L}^{-1}(90$ $\mathrm{Zn}+1.4 \mathrm{Cd}) ; 914 \mu \mathrm{mol} \mathrm{L}{ }^{-1}(900 \mathrm{Zn}+14 \mathrm{Cd}) ;$ and 9,140 $\mu \mathrm{mol} \mathrm{L}{ }^{-1}(9,000 \mathrm{Zn}+140 \mathrm{Cd})$, and $100 \mathrm{~mL}$ of a soil solution with concentrations of 7,140 and $222 \mu \mathrm{mol} \mathrm{L}^{-1}$ of $\mathrm{Zn}$ and $\mathrm{Cd}$, respectively. The soil solution was extracted as described above. After being incubated at $28{ }^{\circ} \mathrm{C}$ for 120 $\mathrm{h}$ with agitation, the cultures were centrifuged at 10,000 rpm for $20 \mathrm{~min}$, and the bacterial pellet was subsequently washed with a solution of $0.1 \mathrm{~N} \mathrm{HCl}$. The pellet was digested in a tube digester using $\mathrm{HNO}_{3}$ as described in USEPA 3050B. The concentrations of the elements were determined via atomic absorption spectrophotometry (City: Überlingen, State: Baden-Württemberg, Country: Germany).

The strains' ability to bioaccumulate $\mathrm{Zn}$ and $\mathrm{Cd}$ was evaluated by calculating their bioaccumulation factor $(\mathrm{BF})$, which is defined as the concentration of the element in the cell biomass compared to the concentration of the element in the culture medium,

$\mathrm{BF}=[\text { Metal }]_{\text {cell biomass }} /[\text { Metal }]_{\text {culture medium }}$

\section{Transmission electron microscopy}

The UFLA02-71 strain was grown in $50 \mathrm{~mL}$ of LB medium supplemented with or without 9,140 mol L-1 HM $(9,000 \mathrm{Zn}+\mathrm{Cd} 140)$ under agitation at $110 \mathrm{rpm}$. After $120 \mathrm{~h}$ of growth, bacterial biomass was harvested by centrifugation at $10,000 \mathrm{rpm}$ for $5 \mathrm{~min}$. The bacterial pellet was homogenized in melted agar/water medium at approximately $50{ }^{\circ} \mathrm{C}$. Small clusters of cells were soon formed upon solidification of the agar, which facilitated handling of the material. This material was then prefixed in $2.5 \%$ glutaraldehyde and $2.5 \%$ paraformaldehyde in a buffer containing $0.05 \mathrm{mmol} \mathrm{L}^{-1}$ cacodylate, pH 7.0 and $0.001 \mathrm{mmol} \mathrm{L}^{-1} \mathrm{CaCl}_{2}$. After $24 \mathrm{~h}$, the material was washed in a $0.05 \mathrm{mmol} \mathrm{L}^{-1}$ cacodylate buffer ( 3 washes for $10 \mathrm{~min}$ ) and post-fixed in $1 \%$ osmium tetroxide in a $0.05 \mathrm{mmol} \mathrm{L}^{-1}$ cacodylate buffer for $2 \mathrm{~h}$. The material was then washed in distilled water $(3$ washes for $10 \mathrm{~min}$ ) and dehydrated in a graded series of acetone, embedded in Spurr epoxy resin and $100 \%$ acetone (1:1) for $5 \mathrm{~h}$ and transferred to pure resin for one night. These blocks were then transferred to molds containing resin and incubated in an oven at $70{ }^{\circ} \mathrm{C}$ for $48 \mathrm{~h}$. The resin blocks were trimmed and prepared for an ultramicrotome. Ultrathin sections (approximately $70 \mathrm{~nm}$ ) were collected on nickel grids covered with Formvar, contrasted with uranyl acetate and lead citrate and examined in a transmission electron microscope (City: Oberkochen, State: Baden-Württemberg, Country: Germany).

\section{Statistical analysis}

Analysis of variance (ANOVA) (SISVAR) and regression analysis were used to analyze the data generated for these strains at different concentrations of $\mathrm{Zn}+\mathrm{Cd}$ and for different incubation periods. The Table Curve 2D for Windows program v. 5.03 was used for the analysis.

\section{Results}

The growth curves of the $C$. necator strains UFLA01-663, UFLA01-659, UFLA02-71 and UFLA02-73 in LB medium with or without $\mathrm{Zn}+\mathrm{Cd}$ are presented in Figure 1. The strains' maximum growth rates were determined using the equations in Figure 1. The maximal growth rates were 9.84 and $9.77 \log \mathrm{CFU} \mathrm{mL}^{-1}$ for the UFLA01-663 and UFLA01-659 strains and 9.44 and $9.48 \log$ CFU $\mathrm{mL}^{-1}$ for the UFLA02-73 and UFLA02-71 strains in culture medium without the metals.

Bacterial growth at concentrations of $9.14,91.4$ to $914 \mu \mathrm{mol} \mathrm{L}{ }^{-1} \mathrm{Zn}+\mathrm{Cd}$ followed the same growth patterns as the bacterial growth in the medium without metal (Figure 1). At these heavy metal concentrations, these strains grew in a log phase for $24 \mathrm{~h}$ and then entered a stationary phase. The maximum growth rates of these strains in the stationary phase at a concentration of $914 \mu \mathrm{mol} \mathrm{L}^{-1}$ of $\mathrm{Zn}+\mathrm{Cd}$ was $9.73 \log \mathrm{CFU} \mathrm{mL} \mathrm{m}^{-1}$ for UFLA01-663, 9.67 log CFU mL $\mathrm{m}^{-1}$ for UFLA01-659, 9.83 $\log$ CFU mL ${ }^{-1}$ for UFLA02-73 and $9.59 \log$ CFU mL ${ }^{-1}$ for UFLA02-71. The growth rate of the strains at the concentration of 9,140 $\mu \mathrm{mol} \mathrm{L}-1 \mathrm{Zn}+\mathrm{Cd}$ was significantly lower than in the presence of lower concentrations of heavy metals, indicating that high concentrations of $\mathrm{Zn}$ and $\mathrm{Cd}$ in solution have a toxic effect on the growth of these strains. The strains grown at the highest concentration of heavy metals had a prolonged period of growth but grew at lower rates than the cultures grown in low concentrations of $\mathrm{Zn}+\mathrm{Cd}$. The growth of these strains continued until $120 \mathrm{~h}$ after inoculation and it was not possible to distinguish the phases of a typical bacterial growth curve. At this concentration of heavy metals, the UFLA02-71 strain exhibited the highest log CFU $\mathrm{mL}^{-1}$ (8.74) after $120 \mathrm{~h}$.

To evaluate the growth of these bacteria in the soil solution, it was necessary to perform the evaluation process of the soil samples again because this experiment required a larger volume of solution. The concentrations of ions found in soil solution were $/ \mathrm{mg}$ $\left.\mathrm{L}^{-1}\right): \mathrm{F}^{-}: 30.67, \mathrm{Cl}^{-}: 3733.53, \mathrm{NO}_{2}^{-}: 16.09, \mathrm{NO}_{3}^{-}: 310.71$, $\mathrm{PO}_{4}^{2-}: 254.44, \mathrm{SO}_{4}^{2-}: 1,433.62, \mathrm{Na}^{+}: 2,960.83, \mathrm{NH}_{4}^{+}$: 378.01, $\mathrm{K}^{+}:$448.03, $\mathrm{Mg}^{2+}: 107.32, \mathrm{Ca}^{2+}:$ 496.86, $\mathrm{Cu}^{2+}$ : 0.50, $\mathrm{Zn}^{2+}:$ 467.00, $\mathrm{Cd}^{2+}: 25.00, \mathrm{~Pb}^{2+}: 0.007, \mathrm{Mn}^{2+}$ : 4.40, $\mathrm{Fe}^{2+}$ : 0.20, total dissolved carbon: 5,850.00 and electrolytic conductivity $\left(\mathrm{mS} \mathrm{cm}^{-1}\right): 2.907$. In this experiment, the strains grew more slowly in the soil solution due to the high concentrations of zinc $(7,140 \mu \mathrm{mol}$ $\left.\mathrm{L}^{-1}\right)$ and cadmium $\left(222 \mu \mathrm{mol} \mathrm{L}^{-1}\right)$ (Figure 2$)$. The behavior of these strains was not similar to a typical microbial growth curve over the $120 \mathrm{~h}$ following inoculation. However, at $120 \mathrm{~h}$, the strains had similar numbers of CFU $\mathrm{mL}^{-1}$ as were observed in the stationary phase of the experiment using LB medium supplemented with $\mathrm{Zn}+\mathrm{Cd}$ at concentrations of 9.14,91.4 and $914 \mu \mathrm{mol}$ $\mathrm{L}^{-1}$ (Figure 1).

When the strains were inoculated into the contaminated soil, there was a $30 \% \log$ reduction in the 
number of cells at the end of 42 days of incubation compared to the original inoculated culture. Nevertheless, the number of viable cells remained high $\left(>10^{6}\right)$, indicating a moderate ability of the strains to survive in contaminated soil (Figure 2).

Notably, there was an increase in the capacity of $C$. necator strains to bioaccumulate $\mathrm{Cd}$ and $\mathrm{Zn}$ ions as the doses of these metals increased (Figure 3). The amounts of zinc retained by these strains at the doses of 9,140 and $9.14 \mu \mathrm{mol} \mathrm{Zn}+\mathrm{Cd}$ were on average 0.16 and $81.49 \mu \mathrm{mol} \mathrm{g}$ cell ${ }^{-1}$. The average amounts of $\mathrm{Cd}$ absorbed by the strains were 0.012 and $13.84 \mu \mathrm{mol} \mathrm{g}$ cell $^{-1}$ at 9.14 and 9,140 $\mu \mathrm{mol} \mathrm{Zn}+\mathrm{Cd}$, respectively. The UFLA02-71 strain had the highest $\mathrm{Zn}$ and $\mathrm{Cd}$ absorption capacity at the higher concentrations of metals in solution compared with the other strains. This strain bioaccumulated
93.76 $\mu \mathrm{mol} \mathrm{g}$ cell-1 of $\mathrm{Zn}$ and $16.03 \mu \mathrm{mol} \mathrm{g} \mathrm{cell-1}$ of $\mathrm{Cd}$. The UFLA02-73 strain also had a high capacity to bioaccumulate Zn (84.48 $\mu \mathrm{mol} \mathrm{g}$ cell $\left.^{-1}\right)$ (Figure 3).

In the soil solution extracted from the contaminated soil, the UFLA02-71 strain bioaccumulated the highest amounts of $\mathrm{Cd}$, corresponding to $16.98 \mu \mathrm{mol} \mathrm{g}$ cell $^{-1}$, whereas the UFLA02-73 strain had the highest levels of zinc absorption at $54.53 \mu \mathrm{mol} \mathrm{g}$ cell $^{-1}$ (Figure 4B). There was an increase in $\mathrm{Cd}$ absorption by strains in the soil solution compared to the medium supplemented with $9,140 \mu \mathrm{mol} \mathrm{L}^{-1}$ of $\mathrm{Zn}+\mathrm{Cd}$ because there was a greater amount of this cation present and available in this solution as the ratio of $\mathrm{Zn}: \mathrm{Cd}$ was 32.16 in this soil solution (Figure 4A). Thus, the higher concentrations of $\mathrm{Cd}$ in the solution contributed to the higher levels of $\mathrm{Cd}$ absorption by these strains.
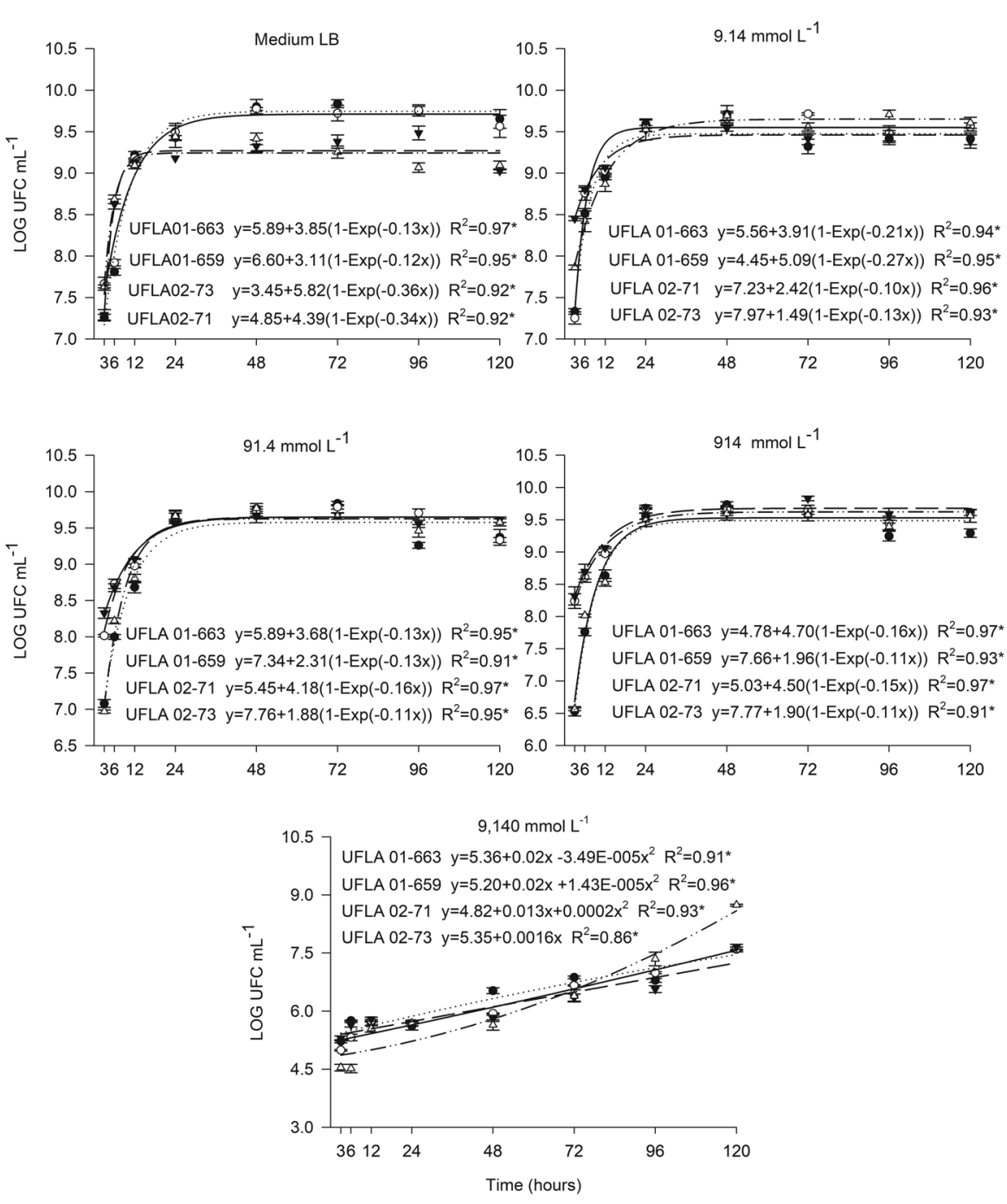

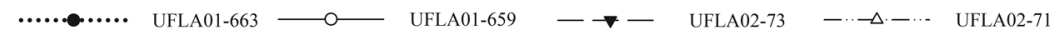

Figure 1 - Number of viable cells of strains UFLA01-663, UFLA01-659, UFLA02-73 and UFLA02-71 in LB liquid medium as a function of time and different concentrations of $\mathrm{Zn}+\mathrm{Cd}$ in the media. The $\mathrm{Zn}: \mathrm{Cd}$ ratio for all concentrations was 64.3. 


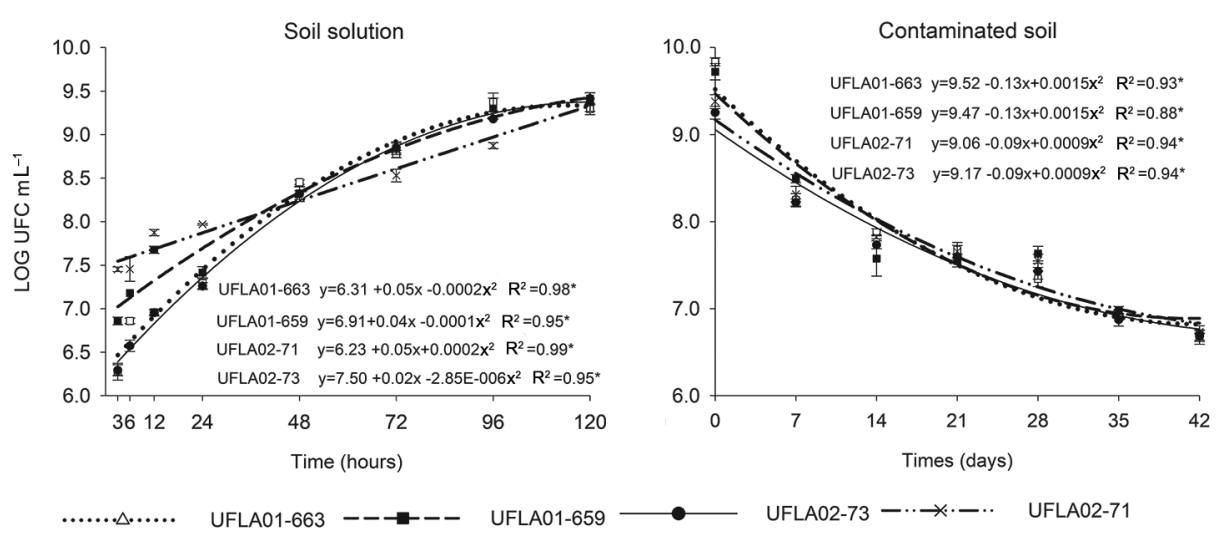

Figure 2 - Numbers of viable cells of the strains UFLA01-663, UFLA01-659, UFLA02-73 and UFLA02-71 in the soil solution and the contaminated soil.

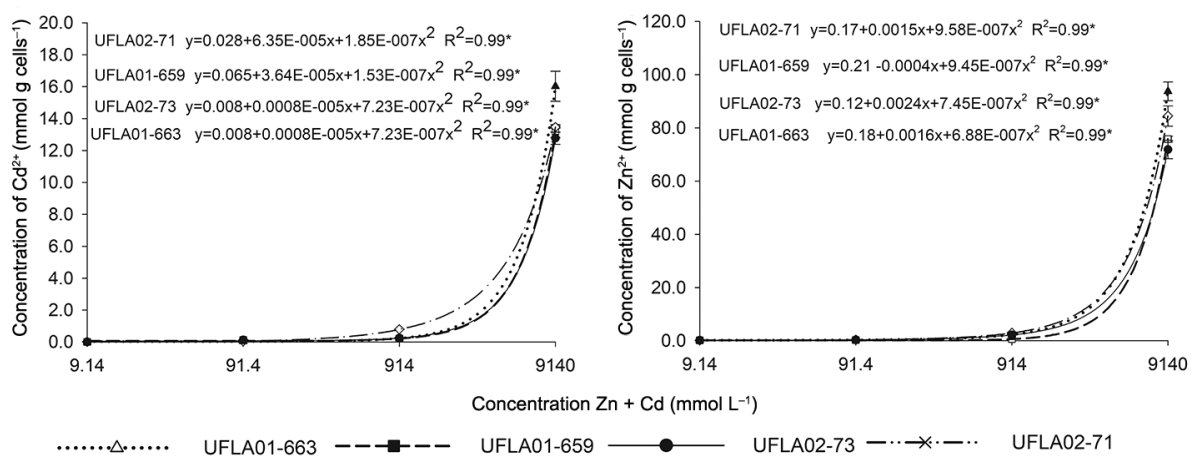

Figure 3 - Concentrations of $\mathrm{Zn}$ and $\mathrm{Cd}$ absorbed by the Cupriavidus necator strains at $\mathrm{Zn}+\mathrm{Cd}$ concentrations of 9,140 $\mu \mathrm{mol} \mathrm{L}^{-1}$ and in the soil solution extracted from contaminated soil.
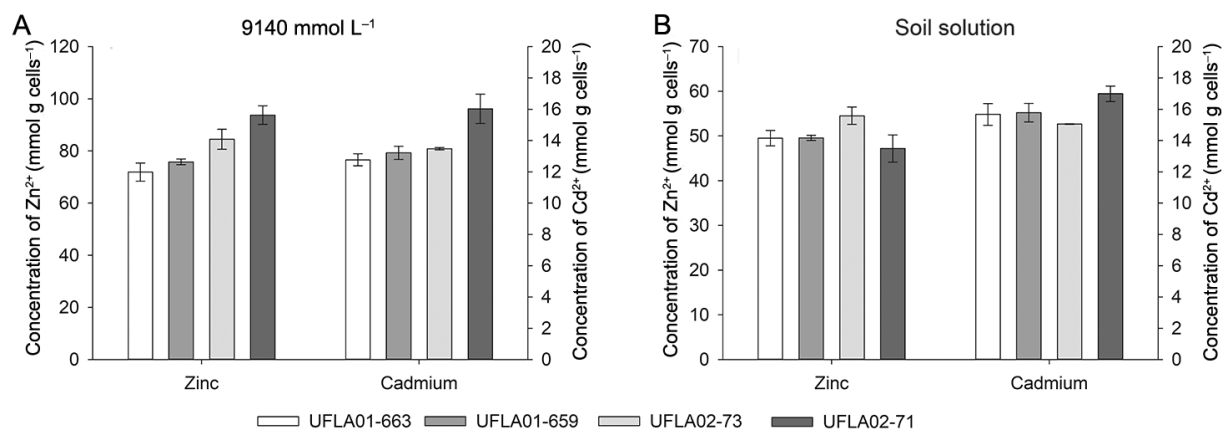

Figure 4 - Concentrations of $\mathrm{Zn}$ and $\mathrm{Cd}$ per strain of Cupriavidus necator grown in the presence of different levels of $\mathrm{Zn} / \mathrm{Cd}$ after $120 \mathrm{~h}$ in 9,140 $\mathrm{mmol} \mathrm{L} \mathrm{L}^{-1}$ of $\mathrm{Zn}+\mathrm{Cd}(\mathrm{A})$ and in the soil solution (B).

After $120 \mathrm{~h}$ of incubation in LB medium supplemented with metals, the bioaccumulation factor $(\mathrm{BF})$ was calculated for all strains at each concentration tested (Table 1). The BF was higher for Cd than for $\mathrm{Zn}$ for all strains, ranging from 65.72 to $787.71 \mu \mathrm{mol} \mathrm{L} \mathrm{L}^{-1}$ for $\mathrm{Cd}$ and 3.04 to $133.49 \mu \mathrm{mol} \mathrm{L} \mathrm{L}^{-1}$ for $\mathrm{Zn}$. These results indicate that these strains have a high capacity for accumulating $\mathrm{Cd}$ inside the cell.
In the experiment using the soil solution, the zinc and cadmium species were measured before growth at $\mathrm{pH} 6.0$ and after growth at $\mathrm{pH} 7.86$ to determine the available forms of these metals in solution (Table 2). The free ions $\mathrm{Zn}^{2+}, \mathrm{Cd}^{2+}, \mathrm{Zn}-\mathrm{DOM} 1$ and Cd-DOM1 decreased as the $\mathrm{pH}$ increased following bacterial growth, which might have reduced the toxic effects of the metals. Conversely, the $\mathrm{ZnHPO}_{4}(\mathrm{aq})$ 
Table 1 - Capacity of bioaccumulation for the Cupriavidus necator strains exposed to increasing concentrations of $\mathrm{Zn}+\mathrm{Cd}$ in culture medium.

\begin{tabular}{|c|c|c|c|c|c|}
\hline & \multicolumn{5}{|c|}{ Concentrations de $\mathrm{Zn}+\mathrm{Cd}\left(\mu \mathrm{mol} \mathrm{L}^{-1}\right)$} \\
\hline & Strains & $\begin{array}{c}9.14 \\
(9.0+0.14)\end{array}$ & $\begin{array}{c}91.4 \\
(90.0+1.4)\end{array}$ & $\begin{array}{c}914 \\
(900+14)\end{array}$ & $\begin{array}{c}9140 \\
(9000+140)\end{array}$ \\
\hline \multicolumn{6}{|c|}{ Factor accumulation } \\
\hline \multirow{4}{*}{$\mathrm{Zn}$} & UFLA02-73 & $73.39 \pm 1.86^{*}$ & $23.88 \pm 0.40$ & $19.19 \pm 1.70$ & $30.10 \pm 2.31$ \\
\hline & UFLA02-71 & $101.47 \pm 1.74$ & $22.47 \pm 3.64$ & $20.69 \pm 1.59$ & $41.90 \pm 0.53$ \\
\hline & UFLA01-659 & $63.37 \pm 2.77$ & $10.02 \pm 0.22$ & $3.04 \pm 0.01$ & $34.37 \pm 1.89$ \\
\hline & UFLA01-663 & $133.49 \pm 13.05$ & $28.10 \pm 2.35$ & $15.85 \pm 0.57$ & $30.86 \pm 2.38$ \\
\hline \multirow{4}{*}{$\mathrm{Cd}$} & UFLA02-73 & $787.71 \pm 15.32$ & $180.69 \pm 17.53$ & $333.94 \pm 21.02$ & $370.17 \pm 2.84$ \\
\hline & UFLA02-71 & $539.63 \pm 14.31$ & $230.21 \pm 2.49$ & $137.16 \pm 31.77$ & $459.92 \pm 19.28$ \\
\hline & UFLA01-659 & $171.27 \pm 6.37$ & $378.48 \pm 5.51$ & $65.72 \pm 4.14$ & $385.60 \pm 30.71$ \\
\hline & UFLA01-663 & $378.71 \pm 11.8$ & $678.71 \pm 7.78$ & $115.70 \pm 22.99$ & $352.07 \pm 11.64$ \\
\hline
\end{tabular}

${ }^{*}$ The standard deviation was calculated based on three replicates.

Table 2 - Percentage distribution of the chemical species of $\mathrm{Zn}$ and $\mathrm{Cd}$ in the soil solutions extracted from the tailings of Votorantim Metals both before bacterial growth (pH 6.0) and after (pH 7.86).

\begin{tabular}{|c|c|c|c|c|c|}
\hline \multirow{2}{*}{ Zinc } & \multicolumn{2}{|c|}{$\mathrm{pH}$} & \multirow{2}{*}{ Cadmium } & \multicolumn{2}{|c|}{$\mathrm{pH}$} \\
\hline & 6.0 & 7.86 & & 6.0 & 7.86 \\
\hline $\mathrm{Zn}^{2+}$ & 8.412 & 7.877 & $\mathrm{Cd}^{2+}$ & 8.337 & 7.675 \\
\hline Zn DOM1 & 83.422 & 81.423 & Cd DOM1 & 52.163 & 50.057 \\
\hline $\mathrm{ZnF}^{+}$ & 0.072 & 0.070 & $\mathrm{CdF}^{+}$ & 0.057 & 0.053 \\
\hline $\mathrm{ZnCl}^{+}$ & 0.747 & 0.710 & $\mathrm{CdCl}^{+}$ & 24.499 & 22.61 \\
\hline $\mathrm{ZnCl}_{2}(\mathrm{aq})$ & 0.039 & 0.041 & $\mathrm{CdCl}_{2}$ (aq) & 5.420 & 5.043 \\
\hline $\mathrm{ZnSO}_{4}(\mathrm{aq})$ & 5.175 & 4.920 & $\mathrm{CdSO}_{4}(\mathrm{aq})$ & 5.495 & 5.189 \\
\hline $\mathrm{Zn}\left(\mathrm{SO}_{4}\right)_{2}^{2-}$ & 1.517 & 1.414 & $\mathrm{Cd}\left(\mathrm{SO}_{4}\right)_{2}^{2-}$ & 2.496 & 2.286 \\
\hline $\mathrm{ZnNH}_{3}^{2+}$ & 0.011 & 0.836 & $\mathrm{CdNH}_{3}^{2+}$ & 0.024 & 1.768 \\
\hline $\mathrm{ZnNO}_{2}^{+}$ & 0.018 & 0.016 & $\mathrm{CdNO}_{2}^{+}$ & 0.259 & 0.229 \\
\hline $\mathrm{ZnNO}_{3}^{+}$ & 0.139 & 0.127 & $\mathrm{CdNO}_{3}{ }^{+}$ & 0.174 & 0.146 \\
\hline $\mathrm{ZnHPO}_{4}(\mathrm{aq})$ & 0.440 & 2.007 & $\mathrm{CdHPO}_{4}(\mathrm{aq})$ & 1.070 & 4.801 \\
\hline $\mathrm{ZnOH}^{+}$ & - & 0.286 & $\mathrm{CdOH}^{+}$ & - & 0.022 \\
\hline $\mathrm{Zn}(\mathrm{OH})_{2}(\mathrm{aq})$ & - & 0.145 & $\mathrm{Cd}\left(\mathrm{NH}_{3}\right)_{2}{ }_{2+}^{2+}$ & - & 0.113 \\
\hline $\mathrm{Zn}\left(\mathrm{NH}_{3}\right)_{3}{ }^{2+}$ & - & 0.015 & - & - & - \\
\hline $\mathrm{Zn}\left(\mathrm{NH}_{3}\right)_{2}{ }^{2+}$ & - & 0.103 & - & - & - \\
\hline
\end{tabular}

and $\mathrm{CdHPO}_{4}(\mathrm{aq})$ species significantly increased as the $\mathrm{pH}$ increased from 6 to 7.84. The species $\mathrm{ZnOH}^{+}$, $\mathrm{Zn}(\mathrm{OH})_{2}(\mathrm{aq}), \mathrm{Zn}\left(\mathrm{NH}_{3}\right)_{3}{ }^{2+}, \mathrm{Zn}\left(\mathrm{NH}_{3}\right)_{2}{ }^{2+}, \mathrm{CdOH}^{+}$and $\mathrm{Cd}\left(\mathrm{NH}_{3}\right)_{2}{ }^{2+}$ were observed only as the $\mathrm{pH}$ increased to 7.84 .

Transmission electron microscopy was used to determine the location of the metal accumulation inside the cells of the UFLA02-71 strain (Figure 5A, B, C and D). The control cells (no metal) displayed a homogeneous cytoplasm without electron-dense granules or PHB (poly- $\beta$-hydroxybutyrate) granules (Figure 5A and B). Cells grown in medium with high concentrations of $\mathrm{Zn}+\mathrm{Cd}$ had both $\mathrm{PHB}$ accumulation and granular deposits in their cytoplasm (Figure 5C). There were no apparent signs of cell lysis or destruction after $120 \mathrm{~h}$ of cultivation in the presence of heavy metals, which is consistent with the observations that this bacterium is able to bioaccumulate toxic elements such as $\mathrm{Cd}$ and $\mathrm{Zn}$ in the interior of its cells (Figure 5D).
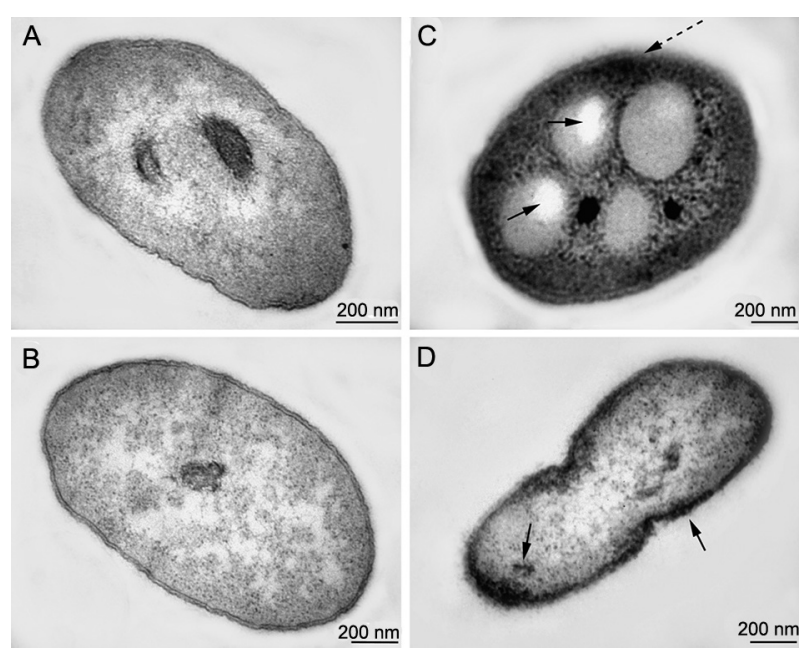

Figure 5 - Transmission electron microscopy of sections of control Cupriavidus necator UFLA02-71 cells (A and B) and Cupriavidus necator UFLA02-71 cells cultured in 9,140 $\mu \mathrm{mol} \mathrm{L}^{-1}$ of $\mathrm{Zn}+\mathrm{Cd}(\mathrm{C}$ and D). Dashed arrow indicates a possible accumulation of metals at these points. Continuous arrows indicate the production of PHB.

\section{Discussion}

The ability of certain microorganisms to grow in the presence of high metal concentrations may result from intrinsic or induced tolerance mechanisms or other environmental factors of the medium (i.e., $\mathrm{pH}$ or redox potential) which may also reduce the toxicity of these metals (Leedjärv et al., 2008; Xiao et al., 2010). Mechanisms have been demonstrated to allow bacterial tolerance to various metals, and these mechanisms vary little between uncontaminated and contaminated environments (Barkay and Schaefer, 2001; Matsuda et al., 2002). This may explain the ability of the strains analyzed in this study to tolerate high concentrations of metals despite being isolated from uncontaminated environments.

In the present study, a relationship was established between the metal tolerance of $C$. necator strains 
in LB medium supplemented with $\mathrm{Zn}+\mathrm{Cd}$ and the metal tolerance in the soil solutions. Under all conditions tested, the strains displayed the same number of viable cells. However, there was a reduction in the number of cells when these strains were inoculated into contaminated soil. Nevertheless, the number of cells remained relatively high given that the metal concentrations in this soil were very high. This reduction in the number of $C$. necator cells in contaminated soil may be due to the exhaustion of carbon sources provided by the culture medium upon inoculation and by the high electrical conductivity of the soil tested $\left(1.60 \mathrm{mS} \mathrm{cm}{ }^{-1}\right)$. These data indicate that it may be possible for these strains to establish a symbiosis with legumes that grow in areas contaminated with heavy metals because of their high tolerance.

Working with a similar soil that was contaminated with different proportions of metals, Matsuda et al. (2002) assessed the growth of strains of genera Bradyrhizobium and Azorhizobium and observed a $20 \%$ survival rate of Bradyrhizobium cells in soil containing 1,250, 206, 67.5 and $192.5 \mathrm{dm}^{-3}$ (Mehlich-I) of $\mathrm{Zn}, \mathrm{Cu}, \mathrm{Cd}$ and $\mathrm{Pb}$, respectively. Conversely, when the survival of the Azorhizobium strains was evaluated, only a small percentage (approximately $2 \%$ ) of cells survived at lower metal concentrations, in this case 750,111, 22.1 and $65.1 \mathrm{mg} \mathrm{dm}^{-3}$ of $\mathrm{Zn}, \mathrm{Cu}, \mathrm{Cd}$ and $\mathrm{Pb}$, respectively. In another study, a strain of Mesorhizobium metallidurans was inoculated into mining tailings that displayed $\mathrm{Zn}$ and $\mathrm{Cd}$ levels of 35,000 and $16.5 \mathrm{mg} \mathrm{kg}^{-1}$, and these strains maintained a constant growth rate of $10^{4} \mathrm{CFU}$ per gram of soil over the 45 days of the experiment (Mahieu et al., 2011). The high tolerance of the $C$. necator strains evaluated in the present study for heavy metals is even more evident than the tolerances seen in previous studies, making the strains examined here potentially useful in revegetation programs for contaminated soils.

Other studies related to the tolerance of bacterial species and the ability of bacterial species to accumulate heavy metals have been published in recent years (Vullo et al., 2008; Chen et al., 2008; Velásquez and Dussan, 2009). However, there are currently no studies in the literature which have a practical focus that consider bacterial growth in soil solutions extracted from contaminated soils. Furthermore, studies examining the ability of $C$. necator to tolerate metals have seldom been performed to date. In a study that examined the C. taiwanensis strain M2, which was isolated from soils contaminated with metals in Argentina, the authors reported maximum bioaccumulation levels of 230 and $125 \mu \mathrm{mol}$ $\mathrm{L}^{-1}$ for $\mathrm{Cd}$ and $\mathrm{Zn}$ when the strain was grown in medium containing $0.5 \mathrm{mmol} \mathrm{L}^{-1}$ of these elements (Vullo et al., 2008). The $C$. taiwanensis strain TJ208, which was isolated from $M$. pudica nodules, showed an estimated maximum adsorption capacity of $19.6 \mathrm{mg} \mathrm{g}^{-1}$ cell for $\mathrm{Cd}$ at a concentration of $100 \mathrm{mg} \mathrm{L}^{-1}\left(893 \mu \mathrm{mol} \mathrm{L}{ }^{-1}\right)$ (Chen et al., 2008). These values show a highest metal accumulation capacity compared to the accumulation capacities of the strains evaluated in this study.
The mechanisms by which microorganisms interact with heavy metals include mechanisms that are independent of or dependent on cellular metabolism. The metabolism-independent mechanisms occur via physicochemical interactions between the metal and cell wall constituents, exopolysaccharide constituents or other materials associated with the external face of the membrane (Naik et al., 2012). These mechanisms are metabolism-independent because energy expenditure by the microbial cell is not required for the absorption of metal ions. Metal removal in this case can occur in both living and dead cells (Gadd, 2004). The transport of metal ions across the cell membrane and their intracellular accumulation is metabolism-dependent and only occurs in living cells capable of generating energy. The removal of these metal ions via this type of mechanism is usually slower than the physicochemical adsorption mechanism. In contrast, larger amounts of metals can be accumulated with these mechanisms (Gadd, 2004), as has been reported for Pseudomonas aeruginosa, $\mathrm{Cu}$ priavidus metallidurans and Bacillus sphaericus (Velasquez and Dussan, 2009). Thus, bacterial mechanisms which tolerate heavy metals (HM) already mentioned, can explain the variation in the ability of bioaccumulation by $C$. necator, depending on the HM concentration in culture medium (Table 1). Metabolic mechanisms allow reductions in metallic ions when $C$. necator is submitted to lower concentrations $\left(9.14 \mu \mathrm{mol} \mathrm{L}^{-1}\right)$ and they do not limit the bioaccumulation ability. On the other hand, mechanisms related to intracelular transport, which reduce bioaccumulation, may occur when toxic concentrations are higher than $91.4 \mu \mathrm{mol} \mathrm{L}^{-1}$ (Vullo et al., 2008).

The $\mathrm{pH}$ of the metal solution plays a very important role in the absorption of metals by microorganisms as it influences the chemical species of metals in solution as well as the surface properties of bacterial cells (López et al., 2000; Pardo et al., 2003). After 120 h of bacterial growth in LB medium containing heavy metals, a $\mathrm{pH}$ reading was performed and demonstrated that there was an overall $\mathrm{pH}$ increase compared to the initial $\mathrm{pH}$, which was adjusted to 6.0 for all experiments. At the concentrations 9.14, 91.4 and $914 \mu \mathrm{mol} \mathrm{L}{ }^{-1}$ of $\mathrm{Cd}+$ $\mathrm{Zn}$, the bacterial strains increased the $\mathrm{pH}$ by an average of $2.2 \mathrm{pH}$ units, whereas in the medium with 9,140 mol $\mathrm{L}^{-1}$ of $\mathrm{Zn}+\mathrm{Cd}$, there was an average increase of $1.9 \mathrm{pH}$ units following bacterial growth. Thus, the strains were able to produce alkalization in the medium capable of reducing the solubility and activity of the metals (Alexander, 1977). An increase in $\mathrm{pH}$ promotes the dissociation of hydroxyl groups $(\mathrm{OH})$ from the medium components that have a predominantly negative charge. The resulting species can then bind to metals, decreasing their availability, and consequently their toxicity.

The toxicity of zinc and cadmium at $\mathrm{pH} 6.0$ for Escherichia coli and Arthrobacter sp. has commonly been associated with the presence of more bioavailable metal species, specifically $\mathrm{Cd}^{2+}$ and $\mathrm{Zn}^{2+}$ (Worden et al., 2009; Moberly et al., 2010). However, other species 
such as $\mathrm{CdOH}^{+}$and $\mathrm{ZnHPO}_{4}(\mathrm{aq})$ in solution may also have a toxic effect on microorganisms. Moberly et al. (2010) reported that the concentration of $\mathrm{ZnHPO}_{4}(\mathrm{aq})$ increased as the $\mathrm{pH}$ increased, favoring a higher absorption of this species into microorganisms due to inorganic phosphate-specific transporters in Arthrobacter sp. In the present study, there was an increase in $\mathrm{ZnHPO}_{4}(\mathrm{aq})$ and $\mathrm{CdHPO}_{4}(\mathrm{aq})$ concentrations in solution as the $\mathrm{pH}$ increased, which may have contributed to the increase in absorption of these metals by the Cupriavidus necator strains (Figure 4B) for other bacterial species as described above by Moberly et al. (2010).

This ability to intracellularly accumulate toxic metals has been reported in members of various other bacterial genera such as Pseudomonas, Bacillus, Sphingomonas, Acidithiobacillus, Arthrobacter and Microbacterium (Kazy et al., 1999; Sar and D'Souza, 2001; Suzuki and Banfield, 2004; Nedelkova et al., 2007; Merroun and Selenska-Pobell, 2008). In these studies, sequestration of these metals was associated with a variety of survival strategies developed by the microorganisms.

In addition to the ability of the $C$. necator strains examined here to bioaccumulate metals, these strains were able to produce PHB in the presence of 9,140 $\mu \mathrm{mol}$ $\mathrm{L}^{-1}$ of $\mathrm{Cd}+\mathrm{Zn}$ (Figure $5 \mathrm{C}$ and $\mathrm{D}$ ). Increased production of PHB by Azospirillum brasilense in the presence of high doses of copper seems to protect bacterial cells from the stress caused by metals (Kamnev et al., 2002; Kamnev et al., 2012).

The genus Cupriavidus is known to have biodegradation abilities and tolerance mechanisms for organic and inorganic pollutants, sparking interest in these microorganisms in the field of environmental biotechnology. Based on the evaluation in this study, the $C$. necator strains analyzed here could be potential tools for the future recovery of areas polluted by mining activities. This tolerance to heavy metals combined with their ability to absorb these metals demonstrates that certain strains of $C$. necator have the potential to decontaminate environments with excess zinc and copper.

\section{Acknowledgements}

We thank the Minas Gerais State Foundation for Research Support (FAPEMIG), Coordination for the Improvement of Higher Level Personnel (CAPES) and Brazilian National Council for Scientific and Technological Development (CNPq) for student fellowships; Fapemig for a research fellowship, grant and for financial support, and CNPq for research fellowships and grants. This publication presents part of the findings of the project titled "Monitoring and Recovery Strategies for Areas Impacted by Mining Activities".

\section{References}

Alexander, M. 1977. Introduction to Soil Microbiology. 2ed. John Wiley, New York, NY, USA.
Barkay, T.; Schaefer, J. 2001. Metal and radionuclide bioremediation: issues, considerations and potentials. Current Opinion in Microbiology 4: 318-323.

Chen, W.M.; James, E.K.; Prescott, A.R.; Kierans, M.; Sprent, J.I. 2003a. Nodulation of Mimosa spp. by the beta-proteobacterium Ralstonia taiwanensis. Molecular Plant-Microbe Interactions 16: 1051-1061.

Chen, W.M.; Laevens, S.; Lee, T.M.; Coenye, T.; De Vos, P.; Mergeay, M.; Vandamme, P. 2001. Ralstonia taiwanensis sp. nov., isolated from root nodules of Mimosa species and sputum of a cystic fibrosis patient. Journal of Systematic and Evolutionary Microbiology 51: 1729-1735.

Chen, W.M.; Moulin, L.; Bontemps, C.; Vandamme, P.; Bena, G.; Boivin-Masson, C. 2003b. Legume symbiotic nitrogen fixation by beta-proteobacteria is widespread in nature. Journal of Bacteriology 185: 7266-7272.

Chen, W.M.; Wu, C.H.; James, E.K.; Chang, J.S. 2008. Metal biosorption capability of Cupriavidus taiwanensis and its effects on heavy metal removal by nodulated Mimosa pudica. Journal of Hazardous Materials 151: 364-371.

Cole, M.A.; Elkan, G.H. 1973. Transmissible resistance to penicillim G, Neomycin, and cloramphenicol in Rhizobium japonicum. Antimicrobial Agents and Chemotherapy 4: 248-253.

Ferreira, P.A.A.; Bomfeti, C.A.; Silva Júnior, R.; Soares, B.L.; Soares, C.R.F.S.; Moreira, F.M.S. 2012. Symbiotic efficiency of Cupriavidus necator strains tolerant to zinc, cadmium, copper and lead. Pesquisa Agropecuária Brasileira 47: 85-95 (in Portuguese, with abstract in English).

Ferreira, P.A.A.; Lopes, G.; Bomfeti, C.A.; Longatti, S.M.O.; Soares, C.R.F.S.; Guilherme, L.R.G.; Moreira, F.M.S. 2013. Leguminous plants nodulated by selected strains of Cupriavidus necator grow in heavy metal contaminated soils amended with calcium silicate. World Journal of Microbiology and Biotechnology 29: 2055-2066.

Florentino, L.A.; Guimarães, A.P.; Rufini, M.; Silva, K.; Moreira, F.M.S. 2009. Sesbania virgata stimulates the occurrence of its microsymbiont in soils but does not inhibit microsymbionts of other species. Scientia Agricola 66: 667-676.

Fred, E.B.B.; Waksman, S.A. 1928. Laboratory Manual of General Microbiology: with Special Reference to the Microorganisms of the Soil. McGraw-Hill, New York, NY, USA.

Gadd, G.M. 2004. Microbial influence on metal mobility and application for bioremediation. Geoderma 122: 109-119.

Goris, J.; De Vos, P.; Coenye, T.; Hoste, B.; Janssens, D.; Brim, H.; Diels, L.; Mergeay, M.; Kersters, K.; Vandamme, P. 2001. Classification of metal-resistant bacteria from industrial biotopes as Ralstonia campinensis sp. nov., Ralstonia metallidurans sp. nov., Ralstonia basilensis Steinle et al., 1998 emend. International Journal of Systematic and Evolutionary Microbiology 51: 1773-1782.

Kamnev, A.A.; Antonyuk, L.P.; Tugarova, A.V.; Tarantilis, P.A.; Polissiou, M.G.; Gardiner, P.H.E. 2002. Fourier transform infrared spectroscopic characterisation of heavy metal-induced metabolic changes in the plant-associated soil bacterium Azospirillum brasilense Sp7. Journal of Molecular Structure 610: 127-131.

Kamnev, A.A.; Tugarova, A.V.; Tarantilis, P.A.; Gardiner, P.H.E.; Polissiou, M.G. 2012. Comparing poly-3-hydroxybutyrate accumulation in Azospirillum brasilense strains Sp7 and Sp245: the effects of copper(II). Applied Soil Ecology 61: 213-216. 
Kazy, S.K.; Sar, P.; Asthana, R.K.; Singh, S.P. 1999. Copper uptake and its compartmentalization in Pseudomonas aeruginosa strains: chemical nature of cellular metal. World Journal of Microbiology and Biotechnology 15: 599-605.

Leedjärv, A.; Ivask, A.; Virta, M. 2008. The interplay of different transporters in the mediation of divalent heavy metal resistance in Pseudomonas putida KT2440. Journal of Bacteriology 190: 2680-2689.

López, A.; Lazaro, N.; Priego, J.M.; Marques, A.M. 2000. Effect of $\mathrm{pH}$ on the biosorption of nickel and other heavy metals by Pseudomonas fluorescens 4F39. Journal of Industrial Microbiology and Biotechnology 24: 146-151.

Louie, T.M.; Webster, C.M.; Xun, L. 2002. Genetic and biochemical characterization of a 2,4,6-trichlorophenol degradation pathway in Ralstonia eutropha JMP134. Journal of Bacteriology 184: 3492-3500.

Mahieu, S.; Fréro, H.; Vidal, C.; Galiana, A.; Heulin, K.; Maure, L. 2011. Anthyllis vulneraria/Mesorhizobium metallidurans, an efficient symbiotic nitrogen fixing association able to grow in mine tailings highly contaminated by $\mathrm{Zn}, \mathrm{Pb}$ and $\mathrm{Cd}$. Plant and Soil 342: 405-417.

Matsuda, A.; Moreira, F.M.S.; Siqueira, J.O. 2002. Tolerance of rhizobia genera from different origins to zinc, copper and cadmium. Pesquisa Agropecuária Brasileira 37: 343-355 (in Portuguese, with abstract in English).

Mergeay, M.; Monchy, S.; Vallaeys, T.; Auquier, V.; Benotmane, A.; Bertin, P.; Taghavi, S.; Dunn, J.; Van der Lelie, D.; Wattiez, R. 2003. Ralstonia metallidurans, a bacterium specifically adapted to toxic metals: towards a catalogue of metal-responsive genes. FEMS Microbiology Reviews 27: 385-410.

Merroun, M.L.; Selenska-Pobell, S. 2008. Bacterial interactions with uranium: an environmental perspective. Journal of Contaminant Hydrology 102: 285-295.

Miles, A.A.; Misra, S.S. 1938. The estimations of the bacteriocidal power of the blood. Journal of Hygiene 38: 732-749.

Moberly, J.G.; Staven, A.; Sani, K.; Peyton, B.M. 2010. Influence of $\mathrm{pH}$ and inorganic phosphate on toxicity of zinc to Arthrobacter sp. isolated from heavy-metal-contaminated sediments. Environmental Science \& Technology 44: 7302-7308.

Naik, M.M.; Pandey, A.; Dubey, S.K. 2012. Biological characterization of lead-enhanced exopolysaccharide produced by a lead resistant Enterobacter cloacae strain P2B. Biodegradation 23: 775-783.

Nedelkova, M.; Merroun, M.L.; Rossberg, A.; Hennig, C.; Selenska-Pobell, S. 2007. Microbacterium isolates from the vicinity of a radioactive waste depository and their interactions with uranium. FEMS Microbiology Ecology 59: 694-705.

Pardo, R.; Herguedas, M.; Barrado, E.; Vega, M. 2003. Biosorption of cadmium, copper, lead and zinc by inactive biomass Pseudomonas putida. Analytical and Bioanalytical Chemistry 37: 26-32.

Sambrook, J.; Fritsch, E.F.; Maniatis, T. 1989. Molecular Cloning: A Laboratory Manual. 2ed. Cold Spring Harbor Laboratory, New York, NY, USA.

Sar, P.; D'Souza, S.F. 2001. Biosorptive uranium uptake by a Pseudomonas strain: characterization and equilibrium studies. Journal of Chemical Technology and Biotechnology 76: 12861294.
Sharaff, M.; Archana, G. 2015. Assessment of microbial communities in mung bean (Vigna radiata) rhizosphere upon exposure to phytotoxic levels of copper. Journal of Basic Microbiology 55: 1299-1307.

Silva, K.; Florentino, L.A.; Silva, K.B.; Brandt, E.; Vandamme, P.; Moreira, F.M.S. 2012. Cupriavidus necator isolates are able to fix nitrogen in symbiosis with different legume species. Systematic and Applied Microbiology 35: 175-182.

Suzuki, S.Y.; Banfield, J.F. 2004. Resistance to, and accumulation of uranium by bacteria from a uranium-contaminated site. Geomicrobiology Journal 21: 113-121.

Taghavi, S.; Mergeay, M.; Nies, D.; Van der Lelie, D. 1997. Alcaligenes eutrophus as a model system for bacterial interactions with heavy metals in the environment. Research in Microbiology 148: 536-551.

Trefault, N.; La Iglesia, R.; Molina, A.M.; Manzano, M.; Ledger, T.; Pérez-Pantoja, D.; Sánchez, M.A.; Stuardo, M.; González, B. 2004. Genetic organization of the catabolic plasmid pJP4 from Ralstonia eutropha JMP134 (pJP4) reveals mechanisms of adaptation to chloroaromatic pollutants and evolution of specialized chloroaromatic degradation pathways. Environmental Microbiology 6: 655-668.

United States Environmental Protection Agency [USEPA]. 1998. Method 3051a: microwave assisted acid digestion of sediments, sludges, soils, and oils. Revision 1. Available at: https://www. epa.gov/sites/production/files/2015-12/documents/3051a.pdf [Accessed July 17, 2017]

van Raij, B.; Andrade, J.C.; Cantarella, H.; Quaggio, J.A. 2001. Chemical Analysis for Fertility Assessment of Tropical Soils = Análise Química para Avaliação da Fertilidade de Solos Tropicais. Instituto Agronômico, Campinas, SP, Brazil (in Portuguese).

Vázquez, S.; Agha, R.; Granado, A.; Sarro, M.J.; Esteban, E.; Peñalosa, J.M.; Carpena, R.O. 2006. Use of white lupin plant for phytostabilization of $\mathrm{Cd}$ and As polluted acid soil. Water, Air \& Soil Pollution 177: 349-365.

Velásquez, L.; Dussan, J. 2009. Biosorption and bioaccumulation of heavy metals on dead and living biomass of Bacillus sphaericus. Journal of Hazardous Materials 167: 713-716.

Vullo, D.L.; Ceretti, H.M.; Daniel, M.A.; Ramírez, S.A.M.; Zalts, A. 2008. Cadmium, zinc and copper biosorption mediated by Pseudomonas veronii 2E. Bioresource Technology 99: 5574-5581.

Worden, C.R.; Kovac, W.K.; Dorn, L.A.; Sandrin, T.R. 2009. Environmental $\mathrm{pH}$ affects transcriptional responses to cadmium toxicity in Escherichia coli K-12 (MG1655). FEMS Microbiology Letters 293: 58-64.

Xiao, X.; Luo, S.L.; Zeng, G.M.; Wei, W.Z.; Wan, Y.; Chen, L.; Guo, H.J.; Cao, Z.; Yang, L.X.; Chen, J.L.; Xi, Q. 2010. Biosorption of cadmium by endophytic fungus (EF) Microsphaeropsis sp. LSE10 isolated from cadmium hyperaccumulator Solanum nigrum L. Bioresource Technology 101:1668-1674. 